\title{
EARLY HOLOCENE MORTUARY PRACTICES IN LAGOA SANTA REGION \\ A 9600-9495 years cal BP Case of Perimortem Body Manipulation from Lapa do Santo (East-Central Brazil)
}

\author{
PRÁTICAS FUNERÁRIAS DO HOLOCENO INICIAL NA \\ REGIÃO DE LAGOA SANTA \\ Um Caso de 9600-9495 anos BP de Manipulação Corporal \\ Perimortem da Lapa do Santo (Centro-Leste do Brasil)
}

\author{
André Strauss ${ }^{1}$ \\ leehstrauss@gmail.com \\ Rodrigo Oliveira ${ }^{2}$ \\ eliaso@usp.br
}

\section{RESUMO}

O sepultamento 21 da Lapa do Santo era composto por um esqueleto adulto quase completo e quase totalmente articulado. Entretanto, as diáfises de ambas as tíbias e fíbulas estavam ausentes. A presença de marcas de corte e de quebra de osso fresco suportam um cenário de manipulação perimortem intencional do cadáver com o intuíto de remover as diáfises. Diretamente datado em 9600-9465 anos antes do presente (calibrado) o sepultamento 21 expande a diversidade de tratamentos funerários encontrados na região de Lagoa Santa durante o Holoceno inicial.

Palavras-chave: Arqueologia da morte, Rituais funerários, Arqueologia brasileira.

\footnotetext{
${ }^{1}$ Museu de Arqueologia e Etnologia, Universidade de São Paulo, MAE-USP.

${ }^{2}$ Laboratório de Arqueologia e Antropologia Ambiental e Evolutiva, Instituto de Biociências, Universidade de São Paulo, IB-USP.
} 


\begin{abstract}
Burial 21 from Lapa do Santo was composed by a single almost complete skeleton that was almost fully articulated. However, the diaphysis of both tibiae and fibulae were absent. The presence of cut marks, chop marks, and green bone fractures are compatible with the intentional perimortem manipulation of the cadaver with the specific goal of removing the diaphysis. Directly dated to 9600-9495 calibrated years before the present Burial 21 further expands the already broad range of mortuary practices known to have characterized human population inhabiting the Lagoa Santa region during the early Holocene.
\end{abstract}

Keywords: Archaeology of death, Funerary rituals, Brazilian archaeology,

\title{
AN INTRODUCTION
}

The mortuary practices of the early Archaic groups that inhabited the New World are still largely unknown. Possibly as a consequence of the rarity of skeletal remains of the proper age, archaeologists have assumed that those populations cope with the dead in very expedite and casual ways, aiming just to get rid of the rotting corpses (Woodburn, 1982) or that cremation was so common that precluded the preservation of skeletal remains (Bird, 1988). However, in the last years this scenario has gradually been challenged.

Santoro and collaborators (2005:330), for example, showed that in the Andes "the manipulation and transformation of dead bodies was more common than previously thought in the study of Archaic mortuary rituals". Strauss (2010) reached similar conclusions for the eastern lowlands, showing that contrary to the classical view, primary burials are not the dominant type of interment in the Lagoa Santa region. Therefore, it seems that, although still incipient, there is a growing consensus that early Archaic burials in South America commonly 
involved the deliberate manipulation of the human body.

Although this new proposition represents an important advancement to our comprehension of the mortuary practices during the early Archaic, the evidence sustaining it is in many cases scarce and fragmentary. A very elementary issue of equifinality is in part responsible for this scenario. In the first place, taphonomic agents can be usually called as an alternative explanation for non-anatomical disposition of skeletal parts that could potentially indicates body manipulation or secundarization (e.g. Silva and Solari, 2017). Besides, even when taphonomic factors can be peremptorily rejected, the archaeologist still has to determine if the disarticulation was a product of the perimortem or of the postmortem intervention of the funerary agents.

The situation gets even more complicated since primary manipulation of the body and secondary deposition of the bones might represent different stages of a single funerary ritual with more than one phase. Confidently establishing such a link is however not trivial, since the complete funerary "chain operatoire" cannot be reconstructed without direct evidence of each one of its steps. In fact, the possibility of reconstructing a whole multi-stage mortuary ritual heavily depends on the diminutive probability of finding the evidence related to each of its stages. Besides, the non-final stages of a multi-stage mortuary ritual are, by definition, transitional and for this reason the probability of finding them in the archaeological record is small. This situation is aggravated when early Holocene 
South American's human remains scarcity is considered. It is not surprising, therefore, that not a single case of a multi-stage funerary ritual has being fully described for this period.

Lagoa Santa region (central Brazil, Figure 1) presents well preserved abundant human remains directly dated to early Holocene, offering a unique opportunity to investigate this matter. In the present contribution we describe the case of Burial 21 from the site of Lapa do Santo and discuss its implications on characterizing the funerary "chain operatoire" in Lagoa Santa region, especially on what concern the initial stages in the processes of long bone midshafts and extremities segregation.
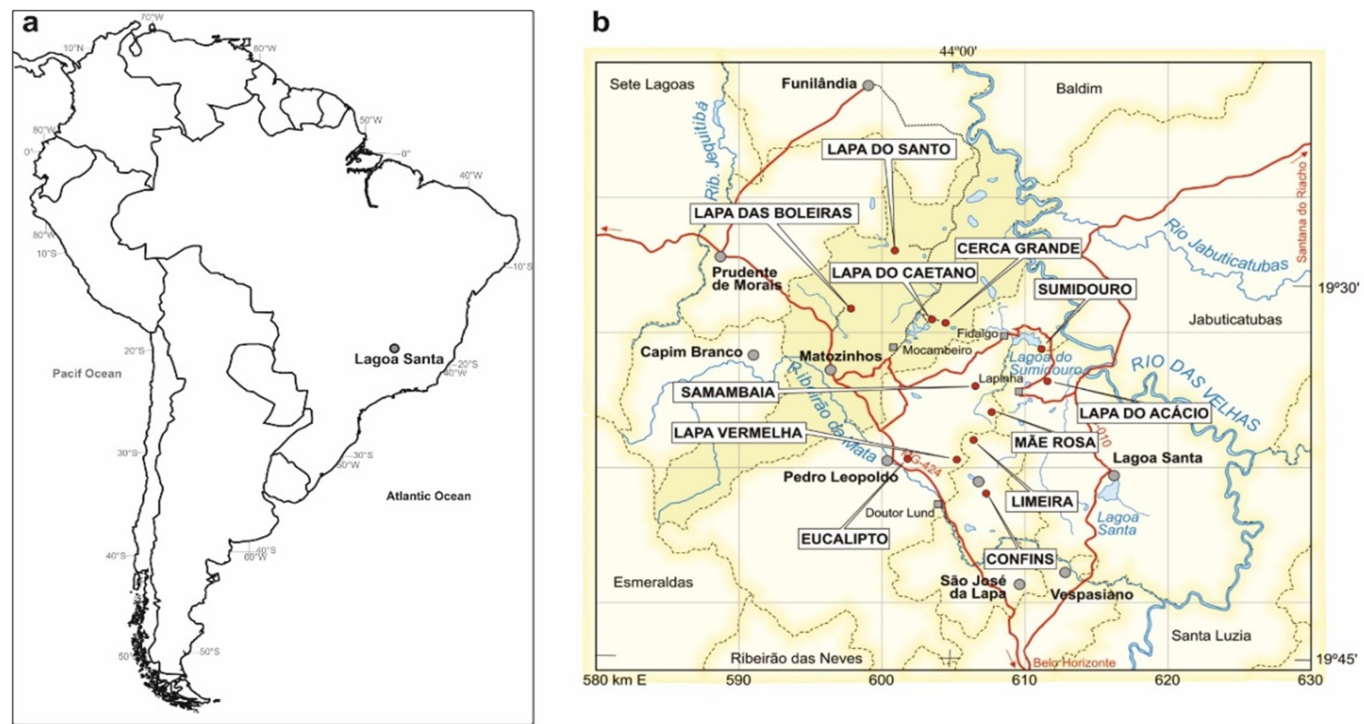

Figure 1. a) Map of South America indicating the location of Lagoa Santa region. b) Regional map of Lagoa Santa indicating the location of the sites discussed in the text. 
To proper contextualize this new finding, a detailed historic revision of the research in Lagoa Santa emphasizing the description of the burials will be initially provided.

\section{THE FUNERARY RECORD OF LAGOA SANTA: A HISTORICAL ACCOUNT}

The first human bones from Lagoa Santa were found by Peter Wilhelm Lund (Piló and Neves, 2002, Hurt and Blasi, 1969; Piló and Auler, 2002; Luna, 2007). Between 1835 and 1843, he visited more than 800 caves in the region, identifying human remains in at least six of them (Cartelle, 1994). Of those, one of particular historical relevance is the one underground cavity located under the massif of the Sumidouro Lake. During most of the time this cave remains flooded with water, but every 30 years or so intense events of drought make it possible to explore its interior. Between 1842 and 1843 Lund was able to explore the cave deposits where he found both human bones and mega-fauna fossils (Neves et al., 2007). For a naturalist trained under the auspicious of Georges Cuvier`s catastrophism those were the findings of a lifetime. For the region of Lagoa Santa the possibility that humans and extinct animals lived together would assure it a long standing world fame and would dominate the research agenda until very recent times.

A detailed description of the fossiliferous content and geological settings of Sumidouro Cave can be found elsewhere (Neves et al., 2007). For the present contribution is important to note that the human bones were not in a typical 
funerary context. There were no pits or graves and no archaeological material was found associated with the bones. However, although mainly of the bones were dispersed through the chamber, without any apparent order, some elements were still in anatomical connection. This made Lund propose that the approximately 30 human skeletons were intentionally thrown in the chamber through a lateral dry entrance. If this was indeed the case it would constitute a unique case in Lagoa Santa and would point to a very peculiar procedure to cope with the dead. However, it is not possible to discard the alternative hypothesis that the human bones got to the chamber together with the mega-faunal bones carried by water through the sinkhole that connects the Sumidouro Lake with the underground chamber (Neves et al., 2007, Lund, 1844). Three direct dates on bones excavated by Lund were recently obtained indicating an early Holocene age for the remains ${ }^{3}$. Besides one cranium that was donated to the $\mathrm{IHGB}^{4}$ and another one that is in the British Museum, Lund's findings were sent to Denmark and are housed at the Zoological Museum Copenhagen.

In spite of figuring in many studies during the $19^{\text {th }}$ (Kollman, 1884; Ten Kate, 1885; Hansen, 1888, Hrdlíčka; 1912) it would take more than 60 years until new excavations took place in Lagoa Santa. Cassio Umberto Lanari was the oldest son of a local farmer and an amateur archaeologist (Lanari, 1909). During the first decade of the $20^{\text {th }}$ century he "explored with enthusiasm, and risking his life,

\footnotetext{
${ }^{3}$ The directed dated bones were excavated in Lapa da Escrivânia (Beta 174734; 7740 \pm 80 BP), Lapa do Baú (Beta 174735; 8830 50 BP) and Lapa do Braga (Beta 17473; $9780 \pm 80$ BP ).

4 IHGB - Brazilian Institute of History and Geography
} 
many labyrinth caves of his father's farm, achieving to find interesting remains, mainly human skeletons from up to three individuals [from Lapa do Caetano], about whom he left a clever post mortem study, published in the Annaes da Escola de Minas" (Padberg-Drenkpol, 1926:3). Immediately after his precocious death in 1910 his findings remained with his family. Later, in 1926, the material was donated to the $\mathrm{MNRJ}^{5}$.

Between June and July of 1926 a researcher from the MNRJ called Jorge Henrique Padberg-Drenkpol coordinated the first Brazilian official scientific excursion in Lagoa Santa. No proper publication is available describing his findings and the following descriptions are based on two unpublished internal reports. Interested in the debate around the possible coexistence of man and megafauna, he initially focused his work on caves and rockshelter previously explored by Lund, such as Cerca Grande 6 and "the particularly famous Sumidouro Cave" (Padberg-Drenkpol, 1926:2). Since the last was under water and he judged the archaeological deposits of the first to be exhausted, he decided to direct his efforts towards the caves explored by Lanari. Both in Lapa do Caetano and Lapa do Cássio he found human burials but no descriptions of their context are available. He only mentions that one of them was found below a thick stalagmite layer suggesting an ancient age and that their skull presented the typical morphology of the "Lagoa Santa race".

5 MNRJ - Museo Nacional do Rio de Janeiro - National Museum of Rio de Janeiro.

6 "Cerca Grande" means "Big Fence". 
Excited by his initial findings, Padberg-Drenkpol organized another expedition to the region from 18th of September to 8th of December of the same year. After exploring without success the rockshelters of Lapa do Zumby, Lapa das Carrancas, Lapa Vermelha de Vespasiano e Lapa da Lagoa dos Mares, he shifted his efforts towards the locality of Confins. There he would discover a cave that was described as the "most fecund mine of archaeological and paleontological remains" of the entire region (Padberg-Drenkpol 1926:3). The Mortuary Chamber of Confins, as the cave was baptized, contained human remains of at least 80 individuals. Descriptions of their context are absent from his reports. He informs, however, that the locality was so rich in human remains that local villagers used to call it "indian cemetery" due to the common finding of bones eroding in the base of the massif. In addition to the human bones, fossils of extinct animals such as horse and mastodon were also found. However, Padberg-Drenkpol point it out that they were found in a different strata and therefore could not be used to prove the co-existence of man and mega-fauna. The material recovered by PadbergDrenkpol is today housed in the MNRJ. Recently, a series of seven direct dates were obtained for these skeletons (see table 10.3.1 in Strauss 2010 for detail on those dates). On one hand they confirm that some of the burials are early Holocene but also point to a significant late Holocene component ${ }^{7}$.

The next team to excavate in Lagoa Santa was coordinated by Harold Walter, the British consul in Brazil at that time. Together with his Brazilian colleagues Aníbal

\footnotetext{
${ }^{7}$ See Strauss 2012 for detailed discussion on the implication of those dates.
} 
Mattos and Arnaldo Cathoud they were ahead of the $\mathrm{AMCL}^{8}$ (Walter, 1958). Between 1933 and 1935 tons of sediment were removed from the same Mortuary Chamber previously excavated by Padberg-Drenkpol. However, while PadbergDrenkpol centered his excavations in the sheltered portion near the entrance of the cave, Walter's excavation was focused in the interior part of the cave. Two meters under the surface, below a stalagmite layer, a human skeleton associated with horse and mastodon bones was located. This skeleton became known as "Confins Man" (for a description in English, see Walter et al., 1937). According to Walter (1958) the skeleton was not formally buried. This allegedly association between Confins Man and mega-fauna's bone was the cause of a heated and not always elegant debate between the groups from Rio de Janeiro and Minas Gerais. Several attempts were recently made to directly date Confins Man but no collagen was retrieved.

After 1935 Walter's team focused only on the paleontological deposits of Lagoa Santa region and it was only in 1948 that they turned their attentions bacj to the archaeological record. In the coming years they would excavate a series of archaeological sites: Lapa do Eucalipto, Lapa da Mãe Rosa, Lapa da Limeira, Lapa do Marciano e Lapa da Samambaia. The findings were described in a bilingual (Portuguese-English) volume published by Walter in 1958.

Lapa do Eucalipto was excavated in 1948, 1949 e 1954. In this locality he found

\footnotetext{
${ }^{8}$ AMCL - Academia Mineira de Ciências e Letras - Academy of Science of Minas Gerais
} 
several human skeletons, some still in articulation due the carbonatic concretion. Of those, 14 were in flexed position, with their hand above the head and with small blocks of stone or cobble above, that were certainly laid there by the occasion of the burial (Walter,1958: 43). In 1949, Harold Walter worked in Lapa da Mãe Rosa. Human bones were found two meters below the surface. They were commingled due to the presence of a heavy stone laid above. No further description of the burials from Mãe Rosa is available. Lapa da Limeira was excavated between 1952 and 1953. "Few" burials were found between 1 and 1.5 meters below the surface. The bones were highly fragmented as a result of trampling (Walter, 1958). An isolated and well-preserved skull was found in the north part of the rockshelter, away from the other burials. The skull had a huge fracture that was the cause of death (Walter 1958). Terraço do Sumidouro is a small terrace formed in the west wall of the Sumidouro massif where a profusion of pre-historic parietal drawings can be observed. Very fragmentary human remains of several individuals were found. Stones above the grave were responsible for the fragmentation. The majority of the skeletons were buried in flexed position between 1 and 2 meters below the surface (Walter, 1958:83).

In 1956 Walter's team returned to the Mortuary Chamber of Confins to excavate the same anthropogenic deposit located in the anterior portion of the cave that Padberg-Drenkpol worked on in 1926. Their goal was to re-evaluate "Confins Man" stratigraphic position within the cave. Not surprisingly, they came to the conclusion that their original interpretation was correct. No proper burial was 
found during the 1956 `s season, but a choped midshafts of a human femur with burning marks was recovered. According to Walter, the bone was crafted into a pipe (Figure 2). This was the first time that an intentionally manipulated human bone is described in Lagoa Santa.

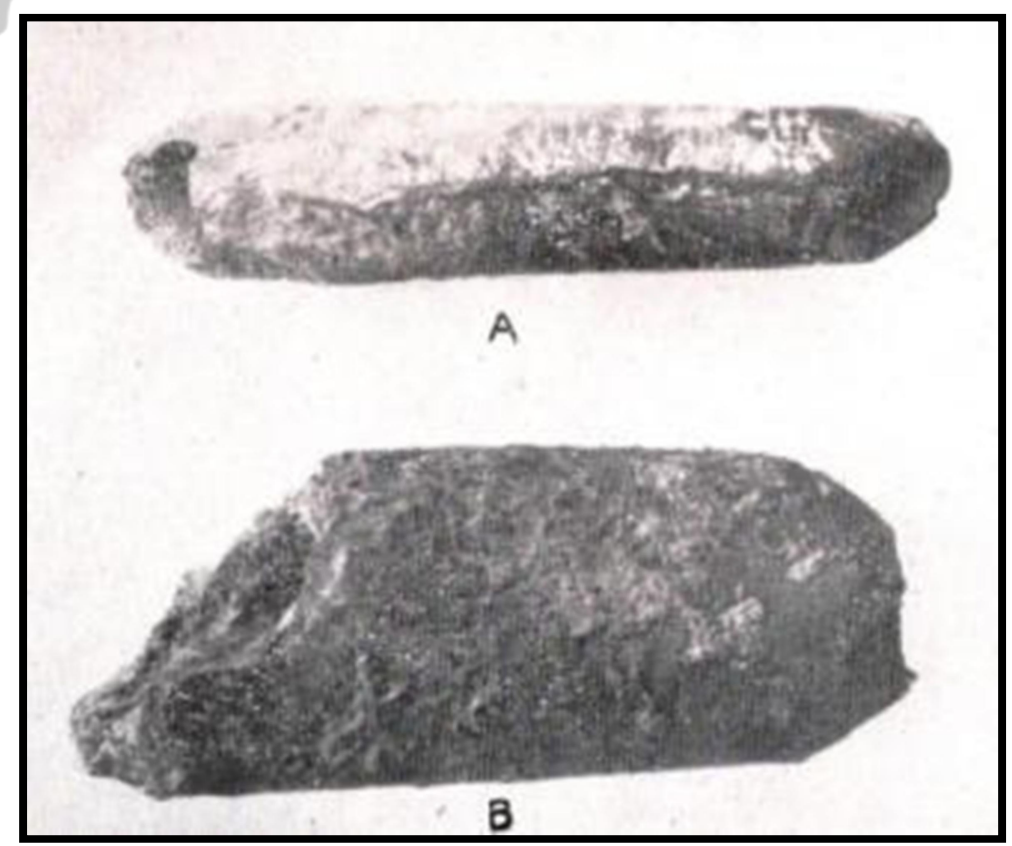

Figure 2. Pieces of human bones originally thought to be pipes found in Lapa Mortuária de Confins by Harold Walter. Reproduced from Walter 1958.

After Walter's death in 1976 it took a long time before his collection was finally donated to the MHN-UFMG ${ }^{9}$. During this period almost all information concerning the provenience of the material was lost. Two exceptions are the skulls from Confins and from Lapa Funda (HW-294). A series of ten direct dates

\footnotetext{
${ }^{9}$ Museo de História Natural da Universidade Federal de Minas Gerais.
} 
recently obtained from bone collagen helped to mitigate this lack of archaeological context. With no exception they are all from early Holocene confirming the antiquity of the material (see table 10.3.1 in Strauss 2010 for detail on those dates). Da-Gloria (2012) computed an MNI of 52 individuals for the Harold Walter collection based on skull counting.

In 1956 a team coordinated by Wesley Hurt from the South Dakota University and Oldemar Blasi from the MNRJ undertook excavations in Cerca Grande, Lapa das Boleiras and Lapa do Chapéu. The original description of these findings is only available in a local publication in Portuguese (Hurt and Blasi,1969).

Cerca Grande is among the largest limestone outcrop in Lagoa Santa presenting a series of seven rockshelters developed next to each other. In Cerca Grande 1, 3 and 4, human skeletal remains were not found. In Cerca Grande 2, four burials were identified. Burial 1 was located 0.34 meters below the surface. The highly fragmented skeleton was flexed with knees touching the face and the arms crossed above the chest. Around the burial a series of stones was vertically deposited.

A scraper made of crystal quartz was found in the grave but judged to be nothing but a fortuitous association. Burial 2 was immediately below the surface and was disturbed by the activity of a previous team of archaeologists preventing proper 
description $^{10}$. Burial 3 was 0.44 meters below the surface. Similar to Burial 1 it was also flexed with knees touching the face and the grave was covered with rocks. Burial 4 was 0.55 meters below the surface and was also in flexed position. However, instead of having stones covering the grave those were below the skeleton (Hurt and Blasi,1969).

In Cerca Grande 5 a total of five burials were recovered. Burial 1 was previously excavated and only some sparse remains were left not allowing a proper description. Burial 2 was very close to the surface. The skeleton was lying over its left side with skull and knees close to each other. The bones were described as highly mineralized with red stains. A "hardened layer of ashes" in the bottom and a hearth near the face were described. Part of the grave was surrounded by stones. Burial 3 was 0.10 meters below the surface. The skeleton was sitting with its head between the knees. Burial 4 was found 0.20 meters below the surface. None of the bones of this child were in anatomical connection. Burial 5 was 0.13 meters below the surface. It was an adult male in flexed position with knees very close to the cranium (Hurt and Blasi, 1969).

Cerca Grande 6 presents the largest archaeological deposit. Burial 1 was located between 0.25 and 0.50 meters below the surface and the majority of the bones

\footnotetext{
${ }^{10}$ It is important to note that in addition to the researchers discussed in this chapter there were also unknown amateur archaeologists excavating sites in Lagoa Santa. In addition, there were also paleontological works in the region that are not mentioned in the present revision since they found no burials.
} 
were broken and not in anatomical position. Even so it was described as a flexed primary interment with crania and knees close together. Stones were covering the grave. Burial 2 and Burial 3 are described together as being located 0.40 to 0.50 meters below the surface. The skeletons were in flexed position. The backs were highly curved and the head was between the knees with the arms crossed over the pelvis. Stones were covering the grave. In 2004 direct dates from bone collagen was obtained for Burial 2 and Burial 3: $8230 \mathrm{BP}$ and $8240 \mathrm{BP}$, respectively. Burial 4 was found between 0.50 and 0.75 meters below the surface in sitting position with knees together with head. Skull and elbows rested over the pelvis with forearms extended forward. Fragments of tree bark were within the grave and could be grave goods (Hurt and Blasi, 1969).

Burial 5 was 0.30 meters below the surface. The skeleton was incomplete with broken bones not in anatomical position. The grave was covered and surrounded by stone slabs. Burial 6 was also represented by few bones and was described to be in flexed position. Burial 7 was 0.40 to 0.50 meters below the surface. Although described as presenting "crushed" bones the archaeologist still described it as a flexed burial. There are no available descriptions for Burials 8 and 9. Burial 10 was in the same layer as Burial 6 and Burial 7 but no further description is available. Burial 11 was 0.50 meter below the surface and it was disturbed, with few bones in their original position. Burial 12 was found under a big rock and only a partial exhumation was possible. No further description is available (Hurt and Blasi, 1969). 
In Cerca Grande 7 only one burial was found. Burial 1 was 0.40 meters below the surface. The skeleton was flexed with knees close to the head and arm crossed over the waist. A layer of stone was covering and surrounding the grave (Hurt and Blasi, 1969).

In Lapa das Boleiras two burials were found. Burial 1 was $0.10 \mathrm{~m}$ below the surface and several bones were missing. Burial 2 was found $1.35 \mathrm{~m}$ below the surface. It was the skeleton of an adolescent lying on its right side in a fully flexed position with knees together with the skull. The American-Brazilian mission also excavated Lapa do Chapéu but no human skeletal remains were found. Two direct dates obtained for skeletons from Cerca Grande 6 are early Holocene (see table 10.3.1 in Strauss 2010 for detail on those dates). All the material retrieved during their excavations was deposited in the MNRJ (Hurt and Blasi, 1969).

Between 1971 and 1976 a French-Brazilian mission leaded by Annette LamingEmperaire explored sites in Lagoa Santa. Lapa Vermelha IV is the only site in which human skeletal remains were found. At 11 meters below the surface coprolites and bones of an extinct sloth were found in a strata dated to $9580 \pm 200$ BP (Laming-Emperaire, 1979). Two meters below the sloth, in an archaeological level dated to 10.2-11.6kyBP a complete adult female skeleton was identified ${ }^{11}$. Some scholars suggested that the skeleton was in situ without any relevant post-

\footnotetext{
${ }^{11}$ This skeleton was nicknamed "Luzia" by Walter Neves.
} 
depositional movement of its constituent's parts (Laming-Emperaire, 1979; Prous, 1986), while others emphasized the disarticulation of the bones implying an important contribution of such post-depositional factors (Cunha and Guimarães, 1978).

If the original stratigraphic assessment of the French team is correct this would be one of the oldest skeletons in the New World. Several attempts to directly date the skeleton failed ${ }^{12}$. Even conservative estimations, however, would postulate an age of ca. $10.5 \mathrm{ky}$ for the skeleton (Feathers et al. 2010; Neves et al., 1999). The skeleton was not found as part of a formal burial since signs of a grave's pit could not be discerned. The material resulting from the French-Brazilian expedition is today housed in the MNRJ.

In addition to the professional academics that worked in Lagoa Santa during the $20^{\text {th }}$ century, it is worth mentioning two amateur explorers that excavated many skeletal remains in the region. The first was Helio Diniz. Very little is known about his work but recently his field notes were made available and they are currently being prepared for future publications.

The second one was a Hungarian refugee called Mihály Bányai who arrived in Brazil in 1957. In 1963 he moved to Lagoa Santa, where he would stay until his death in 2005. Amateur archaeologist in a time when the field was starting to

\footnotetext{
${ }^{12}$ Although no collagen was found the acid-wash material was dated to $9330 \pm 60$. Although this is sometimes interpreted as a "minimum date" we simply disregard this date as not capable of providing any chronological information on Luzia's skeleton.
} 
become professionalized in Brazil he became a controversial figure. Without any formal education he was never accepted by the Brazilian academics. He conducted excavations on his own and created a private little museum in the town of Pedro Leopoldo ${ }^{13}$ where the material is still housed. However, according to Brazilian law archaeological remains belong to the union and therefore a process of "repatriation" is currently ongoing and this material shall in the future be part of a public Brazilian collection. As a consequence, this material was never properly studied and it is not clear when this situation will be settled. The following descriptions are based on a self-edited book in Portuguse published by him in 1997.

In 1970 two adjacent chambers of Lapa da Samambaia were excavated. In the first four skeletons in lateral decubitus were found. No further descriptions are available. The second chamber could only be accessed after the sediment from the first one was removed. He described the presence of two "molehills"14 within this chamber. After close inspection he realized those molehills were actually two skulls belonging to two intertwined skeletons. In the top a child skull ${ }^{15}$, in the bottom the skeleton of an old female. Next to them the remains of a hearth with animal bones. In total 26 skeletons of different age and sexes were recovered. A "black stone pillow" was found under the skull of 25 of these individuals making

\footnotetext{
${ }^{13}$ This is the so called "Museo da Lapinha". Lapinha is the name of an important touristic cave in the region. The museum that was built as a little medieval castle is located next to the cave entrance and is open to the general public.

${ }^{14}$ Translatation for the Portuguese word "montículo".

${ }^{15}$ Bányai estimated it to be 6 to 7 years old.
} 
the locality to be known as "Cemitério de Travesseiros de Pedra"16.

In 1987 he excavated Lapa do Acácio where four articulated skeletons were found between 0.20 and 0.30 meters below the surface. An arrow point made with a bluish raw material was found next to the skull of an old male. This is the only case in Lagoa Santa where a projectile point was deposited as a grave good.

After more than 170 years of archaeological research with hundreds of exhumed skeletons a consensus was established according to which the mortuary rituals of Lagoa Santa were characterized for their simplicity, homogeneity and stability through time. The first to offer a formal description on the subject was Walter (1958):

With no exception the bodies were buried in a flexed position, with knees together with the chin and the arms extended in such way that the hands end up close to or over the head. This used to be a common burial practice among the primitive tribes of entire South America and the custom has being identified in many parts of the world (Neves, 1958: 118)

Four decades later this vision remained unaltered (Neves et al., 2004):

All the burials were similar: the graves were very shallow (maximum $60 \mathrm{~cm}$ in depth), and the bodies were hyper-flexed. Few funerary goods were present, and small stone slabs surrounded and covered the graves (Hurt and Blasi, 1969). As Prous (1991) has emphasized, this is the regular funerary pattern found in the late Paleoindian sites of Lagoa Santa. (Neves et al, 2004: 481).

16" The Stone Pillow Cemetery" 
In 2005, Neves and Hubbe (2005) pushed the argument even further advocating that in Lagoa Santa the mortuary practices were so homogenous and limited in time that they could be used as a chronological marker:

Because of its homogeneity, the burial pattern of the early settling of Lagoa Santa can also be used as a complementary indicator of the chronology of the human remains uncovered when neither stratigraphic control nor direct methods of dating were available (Neves, Hubbe, 2005: 18311).

However, new excavations in Lapa do Santo from 2001 onwards revealed that this traditional view of Lagoa Santa's mortuary ritual was wrong. Far from simple, the burials were sophisticated including perimortem body manipulation, choping of long bones, removal of teeth, exposure to fire, defleshing, decapitation and, potentially, cannibalism. A detailed description of the site and its burials can be found elsewhere (Strauss 2010, 2012, Strauss et al., 2015, Strauss et al., 2016). It is in the context of these new excavations that Burial 21, which is the focus of the present contribution, was found.

\section{BURIAL 21 OF LAPA DO SANTO}

\section{Dating}

A long bone fragment belonging to Burial 21 was pretreated at the Department of Human Evolution, Max Planck Institute for Evolutionary Anthropology (MPIEVA), Leipzig, Germany, using the method described by Talamo and Richards (2011). For acceptable quality collagen, the atomic C:N ratio should be between 2.9 and 3.4 and a collagen yield of more than 1\% of weight (Ambrose, 1990; Van 
Klinken, 1999; DeNiro, 1985). The isotopic results, C:N ratios and collagen yields pf Burial 21's sample were well within the accepted ranges (Table 1) and therefore it was sent to the Klaus-Tschira-AMS facility of the Curt-Engelhorn Centre in Mannheim, Germany, where they have been graphitized and dated (Kromer et al., 2013). The date from MPI was corrected for a residual preparation background estimated from pretreated ${ }^{14} \mathrm{C}$ free bone samples, kindly provided by the ORAU. The resulting radiocarbon date was calibrated using the SHcal13 (Hogg et al., 2013).

\begin{tabular}{|l|l|l|l|l|l|l|l|l|l|l|}
\hline MPI-ID & \%Coll & $\boldsymbol{\delta} 13 \mathbf{C}$ & $\boldsymbol{\delta} 15 \mathbf{N}$ & $\mathbf{\% C}$ & $\mathbf{\% N}$ & $\mathbf{C : N}$ & $\mathbf{1 4 C}$ Age & $\mathbf{1 \sigma}$ Err & $\begin{array}{l}\text { Cal-BP } \\
\mathbf{1 \sigma}\end{array}$ & $\begin{array}{l}\text { Cal-BP } \\
\mathbf{9 5 . 4 \%}\end{array}$ \\
\hline $\begin{array}{l}\text { S-EVA } \\
24497\end{array}$ & 1.4 & -18.59 & 6.40 & 7.31 & 2.75 & 3.10 & 8584 & 33 & $9551-9529$ & $9600-9495$ \\
\hline
\end{tabular}

Table 1. Isotopic values, C:N ratios, amount of collagen extracted (\%Coll) refer to the $>30 \mathrm{kDa}$ fraction. The results of AMS radiocarbon dating of Burial 21. $\delta 13 \mathrm{C}$ values are reported relative to the $\mathrm{vPDB}$ standard and $\delta 15 \mathrm{~N}$ values are reported relative to the AIR standard.

\section{Estimation of sex and age at death}

Burial 21 was composed by the skeleton of a single male individual. Age estimation of the Burial 21 is based on cranial suture, tooth wear, pubic symphysis, and auricular surface. Cranial sutures were scored from the outer and inner table, following Steckel and colleagues's (2006) method. Tooth wear is based on the extrapolation of wear rates from subadults' to adults' molar occlusal wear, using an adaptation of Miles (1963) procedure. Suchey-Brooks method was used to score pubic symphysis (Brooks and Suchey, 1990), whereas Lovejoy and 
colleagues (1985) and Buckberry and Chamberlain (2002) methods were used to the auricular surface. The methods of age estimation resulted in ages from 32 to 60 years old, showing a clear trend towards an older adult. The middle adult category, which ranges from 35 to 50 years old at death, is a good age estimation for this individual.

\section{Burial 21's description}

Burial 21's exhumation was done in consecutive "expositions". In each exposition the maximum amount of sediment was removed without moving or removing any bone. Once this was achieved the burial was documented by mean of pictures and drawings. Then the most exposed bones were removed allowing more sediment to be removed. Figures 3 to 5 show the consecutive expositions.

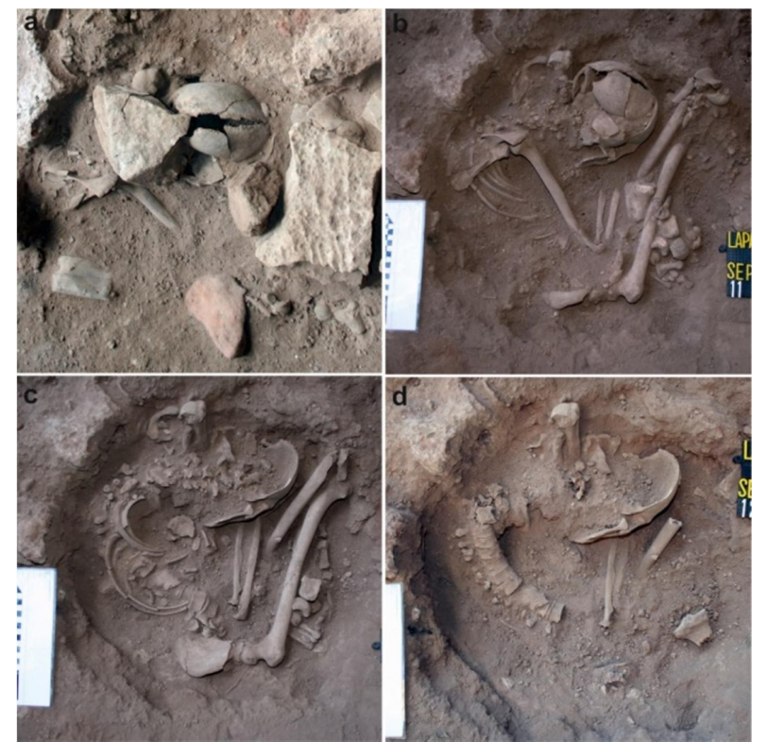

Figure 3. Progressive stages of the exhumation process. 


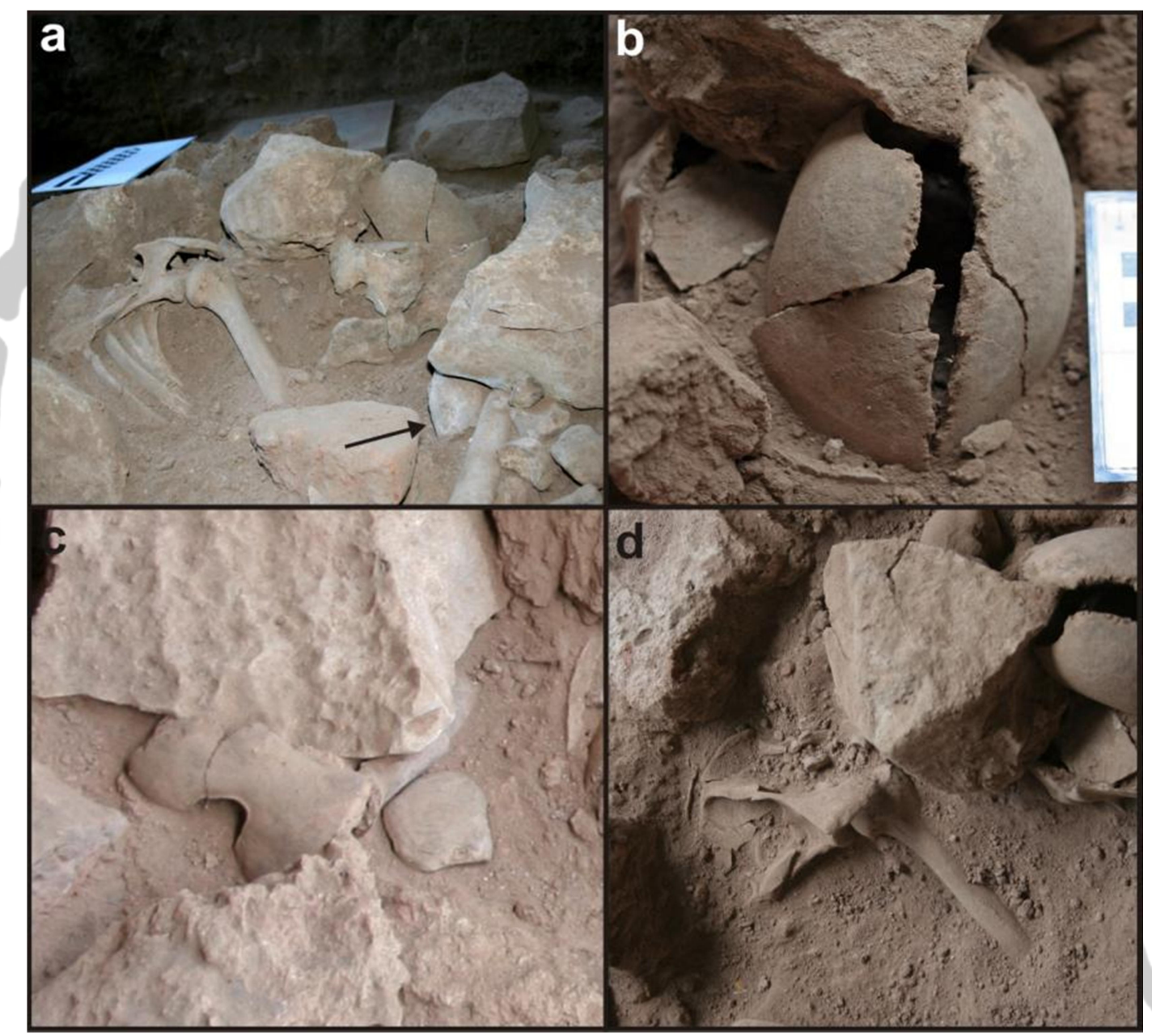

Figure 4. Burial 21. Field pictures. a) Detail of the limestone blocks that were laid over the corpse. The black arrow points to the sectioned proximal extremity of the right tibia that is next to the femur and below a block of limestone; b) detail of the superior part of the cranium. Note that it was empty and that it was fractured due to block deposited above it; c) detail of the left femur that was splashed by the weight of the block deposited above it; d) detail of the articulation of the right shoulder girdle. 


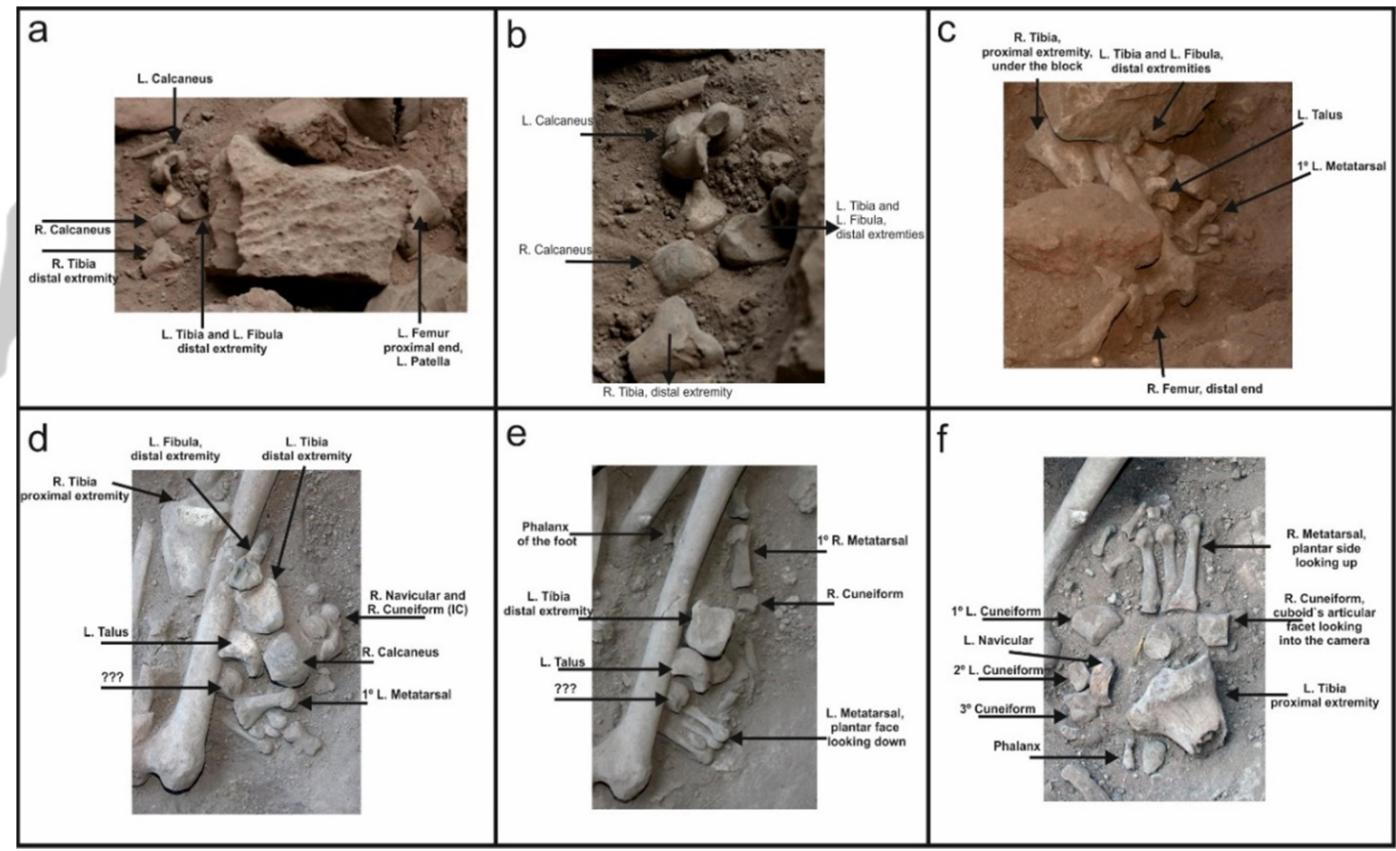

Figure 5. Burial 21. Detail of the region where the bones of the feet and the sectioned extremities of tibia and fibula were located. From "a" up to " $\mathrm{f}$ " consecutive moments of the exhumation are depicted. The identification of the bones was done based on the photographs and not in the field.

The grave was clearly delimited, presenting a circular contour with a diameter of around 0.55 meters. All bones but the midshafts of both tibias and fibulas were present. The skeleton was in left lateral decubitus. The dorsal spine was intensively arched and confined by the grave limits. The hands were located below the skull in such way that the upper and lower arms were fully flexed. The femurs were also flexed, with the knees close to the skull. Five blocks of limestone were deposited above the grave. Two blocks were in direct contact with the bones, probably working as a heavy weight to assure the body would remain within the grave. 


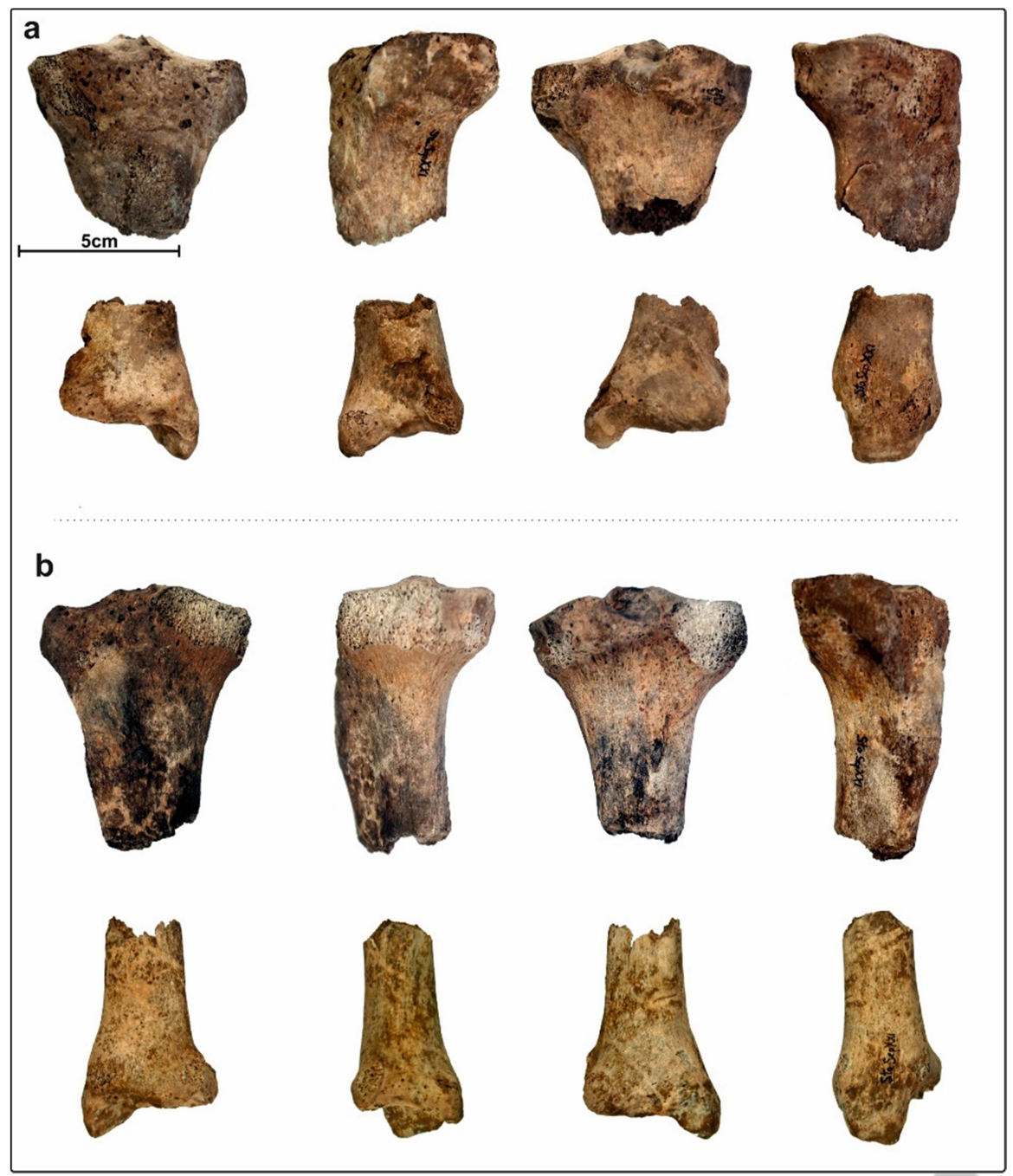

Figure 6 - Burial 21. Sectioned proximal extremity of the right (a) and left (b) tibiae. From left to right: anterior, medial, posterior and lateral views. 


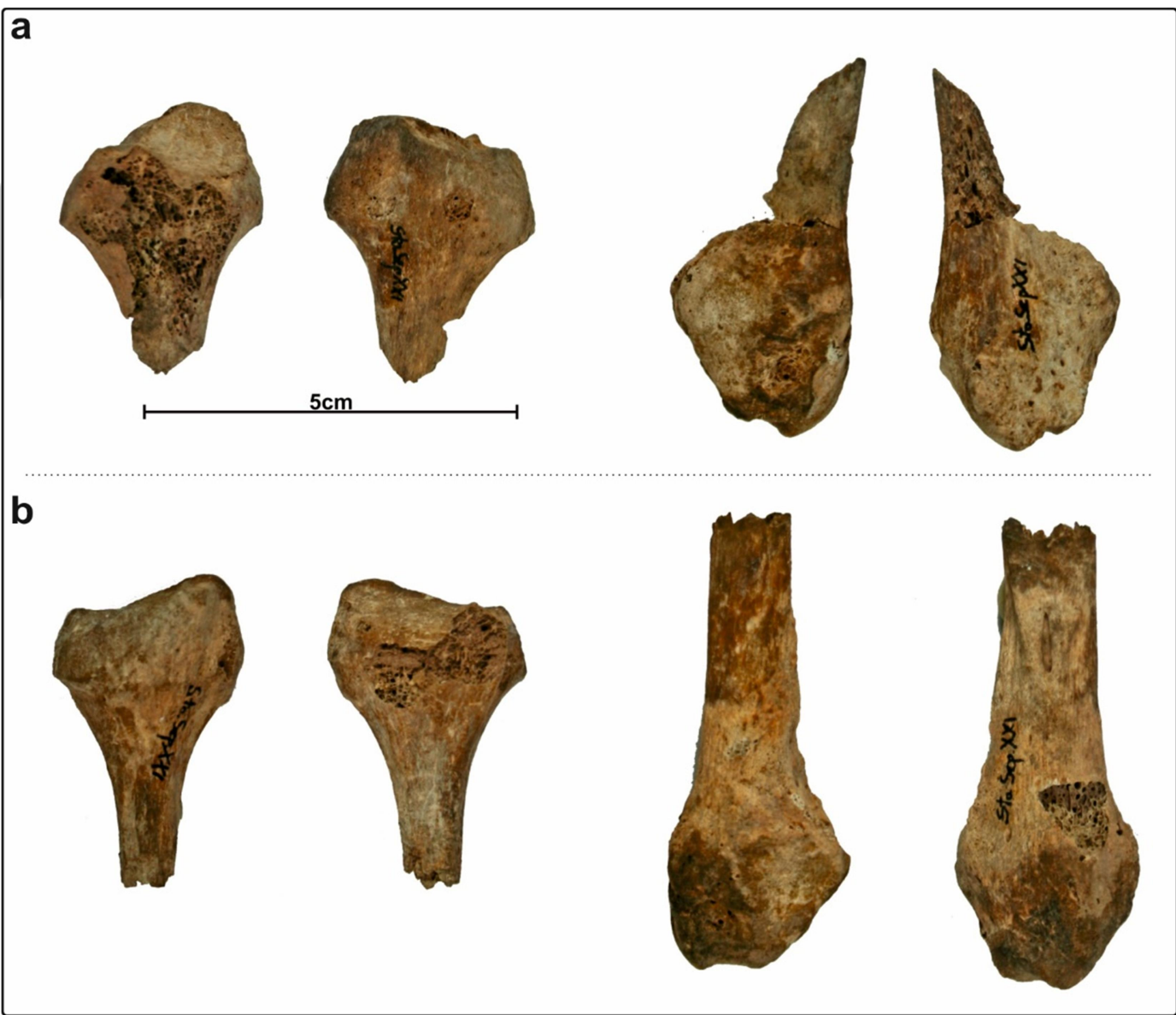

Figure 7 - Burial 21. Sectioned extremities of the right (a) and left (b) fibulae. From left to right: anterior view of proximal extremity, posterior view of proximal extremity, medial view of distal extremity and lateral view of distal extremity.

The skull was facing towards the bottom of the grave, position established with the help of a heavy block that was deposited right above the nape. The weight of the block resulted in the breakage of the neurocranium. The nature of the fracturing, however, suggest this was a postmortem process unrelated to the 
interment. No sediment was found inside the vault. The mandible was in full occlusion with the cranium.

Both tibias and fibulas and the feet's bones weren't in proper anatomical connection with the rest of the skeleton. They were all found together in the southeast portion of the grave (Figure 3). They were located below the right femur near the central part of its midshafts. Only the proximal and distal extremities of both tibias and fibulas were found; the midshafts have been removed. The process by which the midshafts were removed resulted in very distinctive features both in the form of incisions in the bone surface as well as in the morphology of the edges of the sectioned margin of the bone leaving no question concerning its anthropic origins.

The proximal extremity of the left tibia was sectioned into a plane transversal to its long axis located ca. $10 \mathrm{~cm}$ distal to the articular surface. The resulting sectioned margin is straight and presents a very characteristic beveled morphology that is constituted by several chamfers (i.e. chop marks). Besides the chop marks that are constituent parts of the sectioned margin, two chop marks are present in the posterior part of the bone a few millimeters away and parallel to the margin (Fig. 8). This disposition is compatible with "missing" chop marks in the sense they are wrong attempts to section the bone.

Between these two chop marks very fine incisions are observed (Fig. 8). These 
incisions are obliquely oriented in relation to the chop marks and occurred in the form of a sub-parallel cluster. The morphology of those incisions does not suggest they are cut marks. They are too thin. Besides, their transversal profile has a shape of a very open "V", which is incompatible with the sharp edges expected from a cutting flake. Parallel microstriation commonly associated to flake derived cutmarks were also not observed in the SEM image (Figure 9).
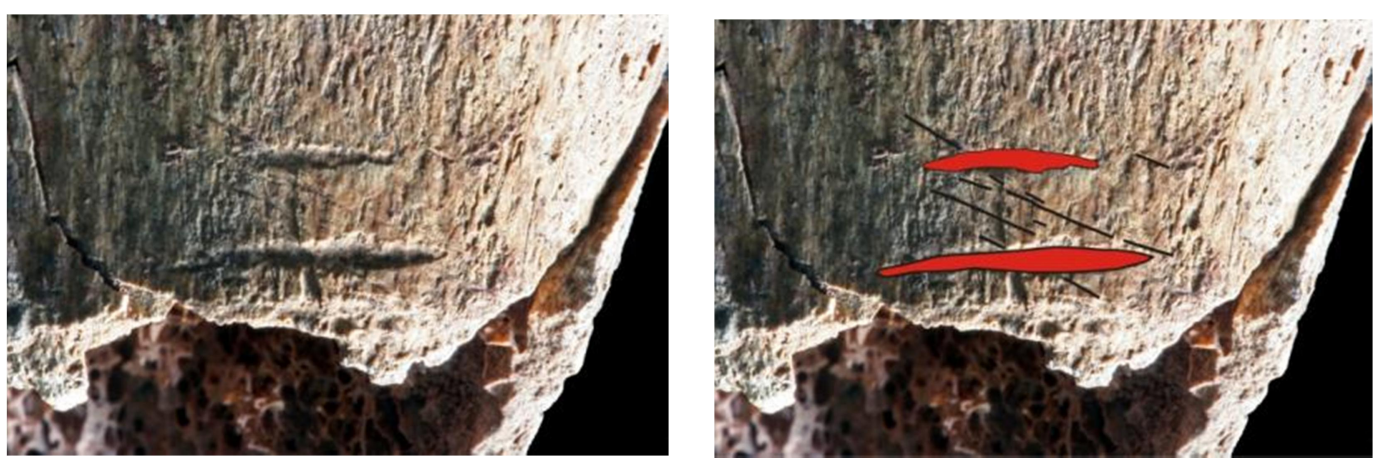

Figure 8. Burial 21. Posterior part of the proximal extremity of the left tibia. Note that there are two different types on incisions. In the image on the right, fine incisions are indicated by the black lines and the chop marks are indicated in red.

The distal extremities of both right tibia and fibula were also sectioned in a transversal plane located at ca. $10 \mathrm{~cm}$ distant to the articular surface (Figures 6 and 7). A beveled morphology is present only in the lateral half of the sectioned margin in both tibias. In both fibulas, it is the lateral half that shows a beveled morphology in the sectioned margin. No chamfers are observed in the surfaces opposite to the beveled margins. 


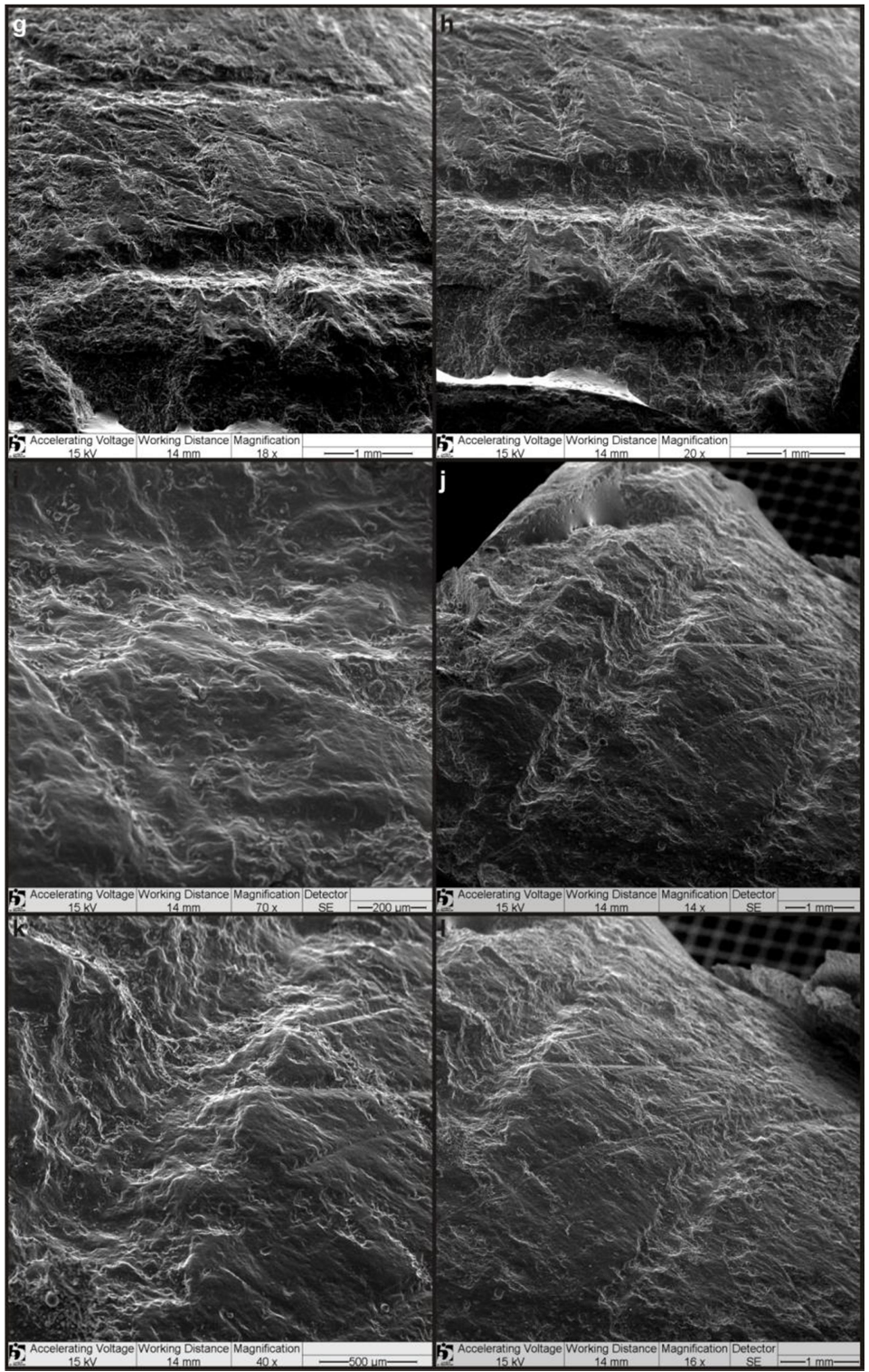

Figura 9. Burial 21. SEM of the proximal extremity of the left tibia MEV da extremidade proximal da tíbia esquerda (continuation). 
The proximal extremity of the right tibia was sectioned into a plane transversal to its long axis located ca. $10 \mathrm{~cm}$ distal to the articular surface. The resulting margin is straight presenting a beveled morphology. Chop marks parallel to this margin were present. These chop marks are clearly the result of hits that missed the target (i.e. gestures that missed the plane through which the bone was being cut). These chop marks are located at the medial and posterior portion of the bone, being absent in its lateral parts. This pattern probably reflects the fact that at the moment cutting took place the lateral part of the tibia was not accessible due to the presence of the fibula. In turns this offers strong support to a scenario of the skeleton being fully articulated at the moment of the manipulation. Oblique to the sectioned margin, there is a single 3 centimeter long incision. Compared to the thin incisions described in the proximal extremity of the left tibia this one is considerable wider.

The distal extremity of the right tibia also has a very characteristic sectioned margin composed by several incomplete chop marks. No complete chop mark was present near the margin. On the other hand a depression of 13 millimeters in length was present. Although not possible to discard a taphonomic origin for this depression, the context of peri-mortem manipulation of this burial makes reasonable to assume this depression was generated by the same type of impact of others complete marks described here. However, since the cortical bone is thinner in this region, a similar blow would generate a broader depression. Besides, observation of internal parts of this depression shows that the surface of the outer 
surface of the cortical bone is still present, what would be compatible with the idea this feature is actually a chop mark.

Likewise the distal right tibia, the beveled morphology of the sectioned margin of the distal extremity of the left tibia is spatially limited to its medial part. In the lateral portion, the cortical bone is intact, even though there is a small fragment of cracked bone at its margin (Figure 10). The fact that the sectioned surface of the distal extremity of the right fibula was not preserved precludes a meticulous analysis as the one done for the left fibula. However, it is reasonable to assume that the restriction of the beveled morphology to the medial side of the tibia is a consequence of limited accesses to the lateral areas due to the presence of the articulated fibula. Therefore, the same procedure postulated previously for the left lower leg can be extended to the right one.

Although not in anatomical connection to the rest of the skeleton many bones of the feet and the distal extremities of tibia and fibula showed some degree of anatomical connection with each other. More specifically the following clusters of bones were in complete anatomical connection: the distal extremity of tibia and fibula, the metatarsal of the right foot, the metatarsus of the left foot, the navicular and cuneiforms. On the other hand, the relative position of the two feet, including the bones of the distal lower leg, was not anatomically coherent. The right foot was below the left one, with its sole facing up, and it was aligned with the right femur with the toes pointing towards the knee and the ankle towards the pelvis. 
The left foot, on the other hand, was perpendicular to the right one with the sole facing down.

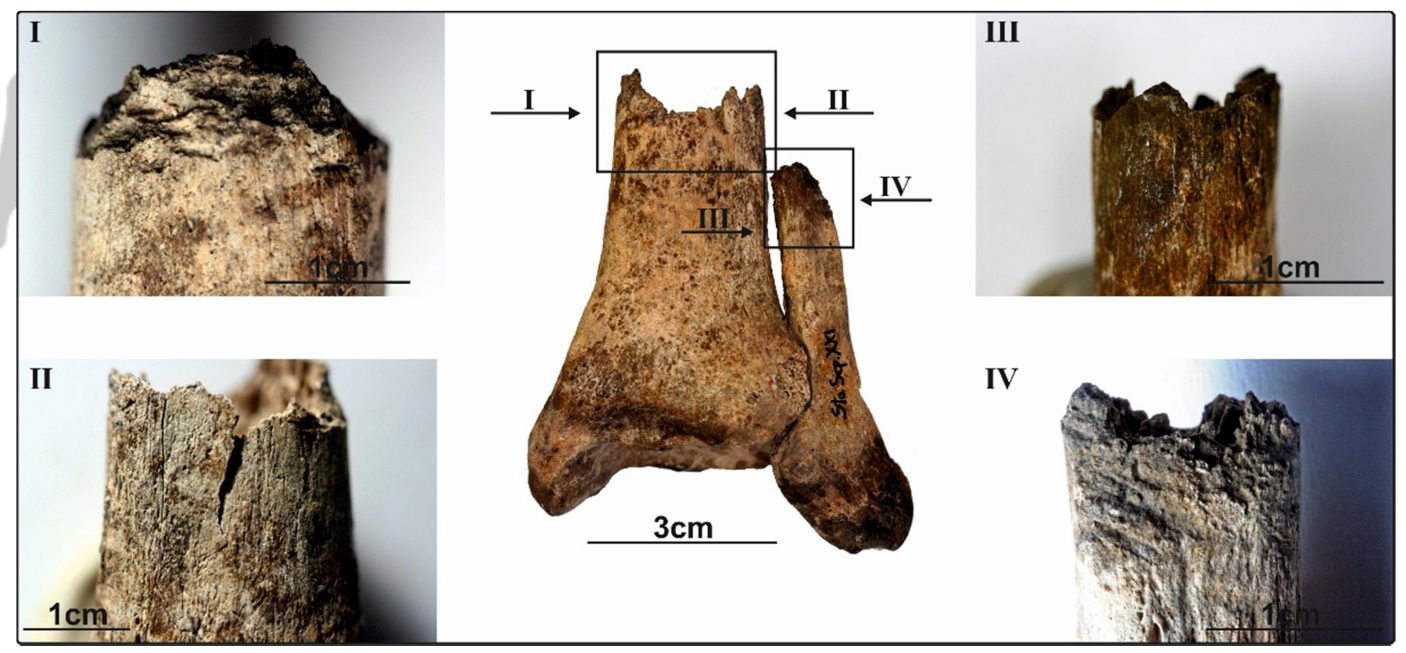

Figure 10. Burial 21. Distal extremities of left tibia and fibula. In the middle tibia and fibula are shown in anatomical position. a) and b) medial and lateral views, respectively, of the cortical surface in the cut region of the tibia; c) and d) medial and lateral views, respectively, of the cortical surface in the cut region of the fibula. Note that in "a)" and in "d)" the cortical surface presents chamfers and presents a typical beveled morphology. In "b)" and in "c)" the cortical surface are not affected by any kind of cutting process. In "b)" there is a fracture that is interpreted as non-taphonomic.

\section{Interment processes and manipulation of the corpse}

The high degree of anatomical connection among the majority of the bones of Burial 21 leaves no doubt that this interment was realized soon after death while soft tissues were still present. However, this does not imply necessarily that the manipulation of the lower leg for the extraction of the midshafts was also realized in a perimortem context. At least in theory it is possible that sometime after the initial inhumation the grave would have been re-opened with the specific aim of 
removing the midshafts of the lower legs. If this procedure could be done in a very meticulous and precise way only bones directly involved would show signs of disturbance.

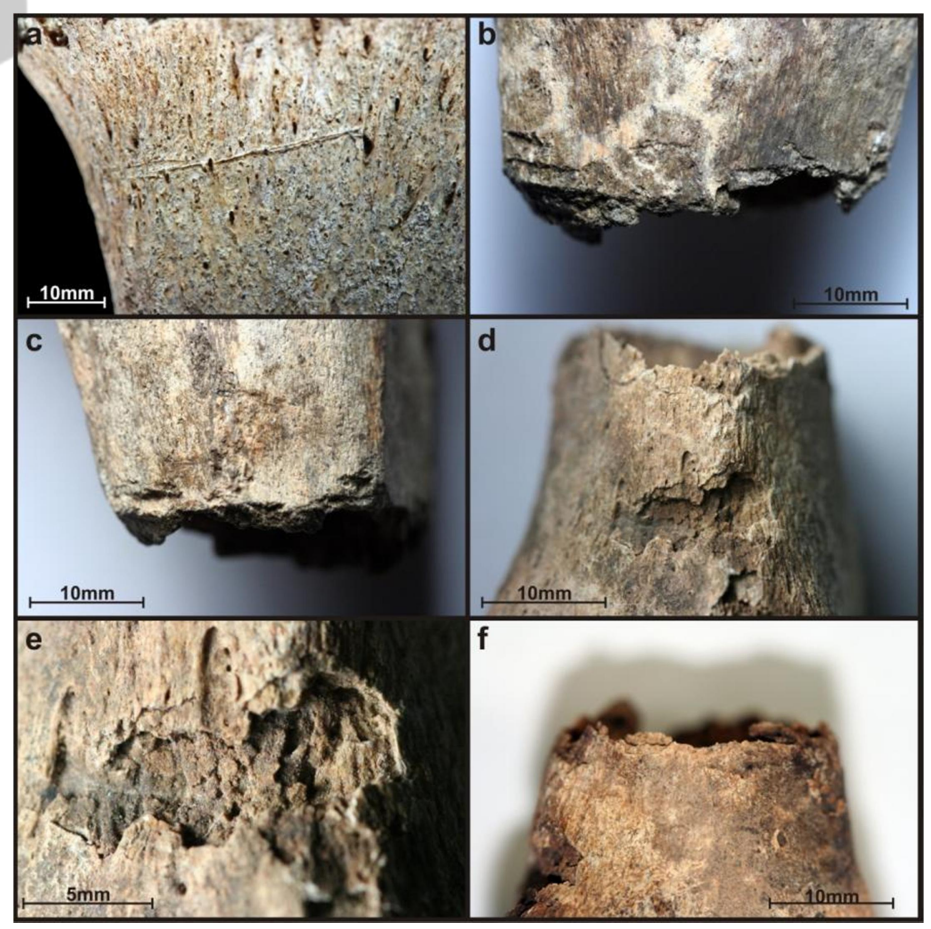

Figure 11. Burial 21's right tibia. a) cut-mark in the posterior part of the proximal metaphysis; b) and c) medial and posterior view, respectively, of the sectioned margin of the proximal chopped extremity. Black arrows point to chop-marks that are outside the sectioned margin and the red arrows to those who are part of the sectioned margin; d) lateral margin of the distal extremity. Black arrows points a depression in the cortical bone that is interpreted as a chop mark and the blue arrow points to a fragmented region on the bone; e) detail of the depression indicate in the previous picture. Note than in the interior part the cortical bone is preserved; f) medial margin of the sectioned surface of the distal extremity. Red arrow points to chop marks that are part of the sectioned margin. 
This could explain the lack of anatomical logic between the proximal extremities of tibia and fibula and the femur. The absence of abundant cut marks characterizing defleshing in both femur and tibia could support this scenario. At the same time, this would be compatible with the high degree of articulation of the rest of the skeleton. Santoro and colleagues (2005) proposed a very similar explanation to the Patapatane burial in which an articulated skeleton was found without some major bones and with the skull not in anatomical connection.

However, such secondary intervention of "chirurgical" nature seems mostly unlikely. Several elements indicate that soft tissues were present not only at the moment of interment but also when the midshafts were removed. The patellae, for example, were in anatomical connection. This would not be expected if the midshaft were removed in a secondary context, regardless of how careful the funerary agents were. Another key aspect in attesting that soft tissues were present during the processes of midshafts extraction is the pattern described above for the distal extremities of left tibia and fibula in which only half of the sectioned surface presented a beveled morphology. This indicates that the action of the cutting instruments used to section the bones were limited to the more accessible surfaces of the lower leg that are in direct contact with the skin (Figure 19). This observation points to a scenario where the skeleton was fully articulated with all soft tissues at the moment of the removal of the midshafts. At the distal extremity of the lower leg, where tibia and fibula articulates, the proximity of these two bones make the region between them quite inaccessible. Of course, this would 
only be the case if the skeleton was fully articulated and with the soft tissues still present. Therefore, this particular disposition of the beveled surface through the sectioned margin offers evidence that at the moment in which the midshafts were removed the particular elements of the body involved were not fully decomposed.

In addition, the lateral margin of the distal extremity of the right tibia presents a little longitudinal crack with characteristics of a green bone fracture. Therefore, it seems that the removal of the midshafts was a procedure involving two steps. Initially the bones were chopped in the regions where they were immediately in contact with the exterior (i.e. in contact to the skin and nearby). This would create a rheologically weaker line in the bone. After that, when the presence of soft tissues (especially muscles of the lower leg), precluded the chopping processes to continue, the bone was tensioned so it would fracture along that weak structural line defined by the former step leading to the separation of the midshaft from the extremities of the bone. It is clear, therefore, that soft tissues were not only present at the moment of interment but also when the midshafts were removed.

Another point concerning the manipulation process that must be discussed is if the sectioning was restricted to the bone or if the procedure resulted in the complete dismembering of the lower leg from the tight and the lower leg from the feet. In other words, were the soft tissues from the regions where the bones were sectioned (ie. distal and proximal extremities of the lower leg) also sectioned? Were leg and tight dismembered from each other or the muscles, tendons and skin 
kept than united? What about the feet (including the distal part of the leg) and the leg? Did the manipulation procedure result in the complete separation of the feet from the rest of the leg, or of the leg from the thigh? Did the whole leg and/or the feet become an independent unity that could be freely moved or soft tissues remained attached to the rest of the body limiting to some extent its mobility?

In respect to the proximal extremity of the leg, the available evidence is not conclusive. If the soft tissues of the articulation weren't cut and, therefore, the lower leg had remained connected to the tight, it would be expected that the proximal epiphyses of the tibias would be in anatomical connection with the distal epiphysis of the femur or, at least, close to them. However, both proximal epiphyses of tibia were found next to the bone of the feet, far away from the expected position. On the other hand, if midshaft removal has being accompanied by the dismembering of thigh from the lower legs, it would be expected to observe a profusion of cut marks associated to defleshing. However, not a single defleshing cut-mark was observed on those bones. Besides, the patellae were in anatomical connection. It is hard to postulate a scenario in which thigh and leg are dismembered and patellae remains in its original position. Although we recognize that the evidence is ambiguous, we believe that the degree of anatomical connection of patella and the absence of cut-marks testify against the hypothesis that lower leg and thigh were dismembered. 
Therefore, the position of the proximal extremities of tibia must be explained by some other mechanism. One possible scenario is that post-depositional movements of the bones occur as a consequence of soft tissues decomposition and gravity`s action. As stated above, there is an important vertical component in the disposition of the skeleton within the grave. Therefore, we believe that when the corpse was buried, after the extraction of midshafts being accomplished, the proximal tibias were in proper anatomical connections with the femurs. After the decomposition of soft tissues, the proximal extremities of both tibias and fibulas would have been detached from the distal femur that was in a higher position in the grave and fall to the bottom of the grave, coming to rest in the position in which they were found.

The following scenario to explain the disposition of the bones observed in Burial 21. The removal of the midshafts was realized soon after death, before inhumation. The manipulation of the body involved the removal of the midshafts, but neither the lower leg was dismembered from the thigh, neither the lower leg was dismembered from the foot. All this parts remained connected by means of muscles, tendons, and skin. No other human intervention involving the corpse happened after the inhumation. Due to the vertical position of the thigh, after the tissues decomposed some bones moved within the grave from a higher to a lower position. This would explain both the position of the proximal extremities of tibia away from the knee and the low disturbance of the bones from the feet. We recognized that we cannot formally reject other possible interpretations but we 
believe this scenario is the most probable.

\section{DISCUSSION}

In Lagoa Santa region, sectioned long bone extremities and midshafts have been long known to occur in secondary context in early Holocene deposits. The first case was described by Walter (1958) who found two pieces of long bone midshafts in the sheltered area of Confins Cave. The cut bones from Confins rockshelter have a very distinctive beveled morphology in their cut margins, indicative of chopping (Da-Gloria et al., 2011). According to Walter (1958:93), these pieces of bones were "tubular pipes made of bone [that were] burned due to use". Recently, Da-Gloria and colleagues (2011) re-analyzed the skeletal remains excavated by Harold Walter in the Lagoa Santa region in search of further evidence of long bone sectioning. They were able to locate 23 cases of mutilated long bones that haven't being reported before. However, in the absence of any information concerning the context in which those specimens were found, it is not possible to fully understand the processes through which they were created nor what were they used for. Contrary to Walter's interpretation of those objects as pipes Da-Gloria and colleagues (2011) claimed that those cut extremities were part of a funerary context.

The association of those cut bones with a funerary context has gained support by new findings from the site of Lapa do Santo. In Lapa do Santo, besides the eight extremities of tibia and fibula associated with Burial 21 described in this 
contribution, eight other cases were also identified. Two of them (distal extremity of femur and a proximal extremity of humerus) were isolated bones not associated to any burial. A proximal extremity of the left ulna and the distal one of the left humerus of the same individual were part of the fully disarticulated Burial 17 (Strauss 2010). Finally, four midshafts of long bones without their extremities were found as part of Burial 18, also in a fully disarticulated context (see Strauss 2010 for detailed description of these burials). These findings showed that that those cut long bones were indeed part of funerary rituals. Besides, direct dates from charcoal samples and bone collagen safely indicated that these mortuary practices are dated to between 8200 and 8800 years BP.

However, in spite of those important improvements in our understanding of the role cut bones played among the groups that inhabited Lagoa Santa, the specific procedure used in order to remove the midshafts and the extremities was yet not known. The particular nature of Burial 21 offers for the first time the opportunity to properly address this question. Burial 21 is a very improbable finding. If our interpretation is correct, this burial represents the initial stages of a funerary ritual that would end up in burials composed by an assemblage of disarticulated bones from different individuals such as Burial 14, 17 and 18 in Lapa do Santo (Strauss 2010). It allows, therefore, avoiding the fundamental problem of equifinality. Also, Burial 21 indicates that extraction of the midshafts was done in a primary context, potentially characterizing a Hertzian case of secundarization where the manipulation of the body and curation of its parts was a central element. Burial 21 
is like the Roseta Stone that allow us to finally understand the origins of those pieces of cut bone found all over Lagoa Santa region.

The low probability of finding such a record of a transitional phase in multi-stage mortuary rituals reflects the fact that, for this specific kind of interment, the funerary ritual was aborted for some unknown reason. It is worth mentioning that the grave of Burial 21 cuts all other burials that are located in the same unit, showing this was probably one of the last interments of a series of pericontemporaneous burials. Strauss $(2010,2011)$ has showed that, although the occupation of the site for non-mortuary purposes continues, this particular group stopped to bury the dead by 8500 BP. It is only almost 700 years later that burials will once again be found in Lapa do Santo. It is tempting to suggest that the reason why Burial 21 did not go into the final stages of the funerary ritual (i.e. disarticulated burials like those mentioned above) is because the group went away from the region or simply vanished.

If we are allowed to extrapolate the findings from Burial 21, the presence of cut epiphyses and long bones in the Harold Walter collection (Da-Gloria et al., 2011) can be taken as an indirect evidence of peri-mortem body manipulation into other funerary context. Therefore, we can postulate that this was an ubiquos practice in the region of Lagoa Santa during early Holocene. It would be important in the future to directly date some of those cut bones found in the Harold Walter collection to test the chronological part of this statement. 
Burial 21 is also relevant in correcting an old bias of interpretation. Walter (1958) has described many burials whose degree of bone fragmentation was very high. Usually, above these burials, rocks were deposited. This observation led Walter to postulate that the fragmentation of the bones were a result of the overweight of the blocks. However, Burial 21 shows that blocks deposited above the skeleton do not necessarily generate such fragmentation. This support the interpretation offered in Strauss (2011) that fragmentation of those skeletons was a result of the mortuary rituals and not consequence of blocks overweight.

Besides being an important finding in the regional level, Burial 21 also has implications in the continental scale. In spite of the recent recognition that Early Archaic mortuary practices in South America frequently involved some sort of body manipulation (Rossen and Dillehay, 2001; Santoro et al., 2005; Strauss, 2010), the available evidence is still sparse. Several examples from the South American Archaic funerary record illustrate how difficult it can be to fully reconstruct the "chain operatoire" of a funerary ritual. Cardich (1964:107), for example, believed that Burial 5 from Lauricocha represented a "mutilated interment", but he wasn't able to prove that the absence of some specific bones could not be explained by taphonomic agents. In sites associated to the Nanchoc tradition in Peru, Rossen and Dillehay (2001:64) have inferred that cutting and breaking bones were part of the mortuary practices, but due to the fragmentary nature of the findings they weren't able to qualify this statement any further. In 
Nemocon, it was assumed that the calcination process that led to the observed concentration of burned bones was realized soon after death. However, the only evidence to sustain that conclusion is the absence of ash in the pits.

In this context, Burial 21 is an important finding. It shows clear and undisputed evidence of peri-mortem body manipulation, constituting the oldest case in the New World in which this behavior is directly observed. Therefore, Burial 21 assumes a relevant role in respect to the growing efforts of better characterizing the funerary rituals of the Early Archaic hunter-gatherers. It not only confirms the conclusions of Santoro and colleagues (2005:330) that reduction of body was a major element in the funerary rituals during this time frame but also show that this was not at all limited to the Andean region. On the contrary, when the indirect nature of the Andean findings are taken into account, Burial 21 becomes the most clear and expressive case of peri-mortem manipulation in the continent.

\section{CONCLUSIONS}

Burial 21 is directly dated to the early Holocene and constitutes one of the clearest case of perimorten body manipulation in the New World during this period. The abundance of cut-marks and the spatial distribution of the remains leave no space for postulating an accidental explanation for the findings (eg. grave intercepted by reuse of space). The analysis of the cut-marks indicates stone flakes were the instruments used for the removal of the diaphysis of both tibiae and fibulae. The removed bones were later inhumed as part of secondary burials. Therefore we 
suggest the manipulation of the fresh corpses in Lapa do Santo were not related to trophy taking but part of a broader set of ritualized funerary prescription. The presence of such practices in east-central Brazil expands its known range of occurrence in South America showing that funerary rituals focusing on the manipulation of the body was present in the east part of South America during the early Archaic.

\section{REFERENCES}

AMBROSE, S. H. Preparation and characterization of bone and tooth collagen for isotopic analysis. J. Archaeol. Sci. 17, 431-451 (1990).

BÁNYAI, M. Minhas pesquisas arqueológicas na região de Lagoa Santa. Symbiose. 1997.

BROOKS, S.T; SUCHEY, J.M. 1990. Skeletal age determination based on the os pubis: a comparison of the Ascádi-Mereskéri and Suchey-Brooks methods. Human Evolution 5:227-238, 1990 .

BROWN, T. A., Nelson, D. E., Vogel, J. S. \& Southon, J. R. Improved collagen extraction by modified Longin method. Radiocarbon 30, 171-177 (1988).

BUCKBERRY J.L.; CHAMBERLAIN, A.T. Age estimation from the auricular surface of the ilium: A revised method. American Journal of Physical Anthropology 119:321-329, 2002.

CARDICH A. Lauricocha - Fundamentos para uma prehistoria de los Andes Centrales. Buenos Aires, Argentina. 1964.

CARTELLE, C. Tempo passado: mamíferos fósseis em Minas Gerais. Editora Palco, Bole Horizonte. 1994.

CUNHA, F.L.S.; GUIMARÃES, M.L. Posição geológica do homem de Lagoa Santa no grande abrigo de Lapa Vermelha Emperaire Pedro Leopoldo - Estado de Minas Gerais. In: Coletânea de Estudos em Homenagem a Annette Laming-Emperaire. Museu Paulista 
da Universidade de São Paulo. 1978.

DAGLORIA, P.T.; STRAUSS, A.; NEVES, W.A. Mortuary rituals in the Early Holocene population of Lagoa Santa: The Harold Walter collection (Poster presentation). In: 80th anual meeting of the American Asociation of Physical Anthropology, Minneapolis (USA). American Journal of Physical Anthropology 144(S52): 119. 2011.

DA-GLORIA, P. Health and lifestyle in the Paleoamericans: early Holocene biocultural adaptation at Lagoa Santa, central Brazil. Unpublished Ph.D. dissertation, The Ohio State University. 2012.

DENIRO, M. J. Postmortem preservation and alterarion of in vivo bone collagen isotope ratios in relation to palaeodietary reconstruction. Nature 317, 806-809 (1985).

FEATHERS, J.; KIPNIS, R.; PILÓ, L.; ARROYO-KALIN, M.; COBLENTZ, D. How old is Luzia? Luminescence dating and stratigraphic integrity at Lapa Vermelha, Lagoa Santa, Brazil. Geoarchaeology 25: 395-436, 2010.

HANSEN, S. Lagoa Santa racen. En Anthropologisk Undersogelse af Jordfundne Menneskelevninger fra Brasilianske Huler. Med et Tillaeg om det Jordfundne Menneske fra Pontimelo, Rio de arrecifes, La Plata.1888.

HIGHAM, T. F. G.; JACOBI, R. M.; BRONK RAMSEY, C. AMS radiocarbon dating of ancient bone using ultrafiltration. Radiocarbon 48, 179-195 (2006).

HOGG, A. G. et al. SHcal13 southern hemisphere calibration, 0-50,000 years cal BP. Radiocarbon 55, 1889-1903 (2013).

HRDLÍČKA, A. Early Man in South America. Bureau of American Ethnology Bulletin No 52. Washington, EUA. 1912.

HURT, W.; BLASI, O. O Projeto Arqueológico Lagoa Santa - Minas Gerais, Brasil (nota final). Arquivos do Museu Paranaense - Arqueologia 4:1-63. 1969.

KOLLMAN, J. Schadeln von Lagoa Santa. Z. Ethnol 16:194-199, 1884.

KROMER, B.; LINDAUER, S.; SYNAL, H.-A.; WACKER, L. MAMS - A new AMS facility at the Curt-Engelhorn-Centre for Achaeometry, Mannheim, Germany. Nucl. 
Instruments Methods Phys. Res. Sect. B Beam Interact. with Mater. Atoms 294, 11-13 (2013).

LAMING-EMPERAIRE, A. Missions archéologiques franco-brésiliennes de Lagoa Santa, Minas Gerais, Brésil - Le Grand abri de Lapa Vermelha. Revista de Pré-história 1:53-89, 1979.

LANARI, C.U. Ossadas humanas fósseis encontradas numa caverna calcárea das vizinhanças do Mocambo. Annaes da Escola de Minas de Ouro Preto 11:15-35, 1909.

LONGIN, R. New method of collagen extraction for radiocarbon dating. Nature 230, 241-242 (1971).

LOVEJOY, C.O.; MEINDL, R.S.; PRYZBECK, T.R.; MENSFORTH, R.P. Chronological metamorphosis of the auricular surface of the ilium: a new method for the determination of adult skeletal age at death. American Journal of Physical Anthropology 68:15-28, 1985.

LUNA, P.E. Peter Wilhelm Lund: o auge das suas investigações cientificas e a razão para o término das suas pesquisas. Tese de Doutorado. Faculdade de Filosofia Letras e Ciências Humanos, Universidade de São Paulo.2007.

LUND, P.W. Notícia sobre ossadas humanas fósseis achadas numa caverna do Brasil. In: Paula Couto C. (Ed.) Memórias sobre a paleontologia brasileira. Instituto Nacional do Livro, Rio de Janeiro. 1844.

MENDONÇA DE SOUZA, S.M.F.; RODRIGUES-CARVALHO, C.; SILVA, H.P.; LOCKS, M. Revisitando a discussão sobre o Quaternário de Lagoa Santa e o povoamento das Américas: 160 anos de debates científicos. In: SILVA, H.P.; RODRIGUESCARVAlHO, C. (eds.) Nossa origem - o povoamento das Américas visões multidisciplinares. Rio de Janeiro: Vieira \& Lent Casa Editorial, 2006.

MILES, A.E.W. Dentition in the assessment of individual age in skeletal material. In: BROTHWELL, D.R. (ed) Dental anthropology. Oxford Pergamon. p. 191-209, 1963.

NEVES, W.A.; HUBBE, M. Cranial morphology of early American from Lagoa Santa, Brazil: Implications for the settlement of the New World. Proceedings of the National Academy of Sciences of the United States 102:18309-18314, 2005. 
NEVES, W.A.; POWELL, J.F.; PROUS, A.; OZOLINS, E.G.; BLUM, M. Lapa Vermelha IV Hominid 1: Morphological affinities of the earliest known American. Genetics and Molecular Biology 22:1-5, 1999.

NEVES, W.A.; GONZÁLEZ-JOSÉ, R.; HUBBE, M.; KIPNIS, R.; ARAUJO, A.G.M.; BLASI, O. 2004. Early Holocene human skeletal remains from Cerca Grande, lagoa Santa, Central Brazil, and the origins of the first Americans. World Archaeology 36:479501,2004

NEVES, W.A.; HUBBE, M.; PILÓ, L.B. Early Holocene human skeletal remains from Sumidouro Cave, Lagoa Santa, Brazil: History of discoveries, geological and chronological context, and comparative cranial morphology. Journal of Human Evolution 52:16-30, 2007.

PADBERG-DRENKPOL,J.H. Relatório interno do museu nacional.1926.

PILÓ, L.B.; AULER, A.S. Apresentação: bicentenário de Peter Wilhelm Lund (18011880). O Carste 14:4-7, 2002.

PILÓ, L.B.; NEVES, W.A. A coexistência do homem com os grandes mamíferos extintos e a origem do homem no novo mundo, Segundo Peter Wilhelm Lund (1801-1880). CRONOS n ${ }^{\circ} 5.2002$.

PROUS, A. L'Archéologie au Brésil. 300 Siécles d'occupation humaine. L'anthropologie 90:257-306, 1986.

ROSSEN, J.; DILLEHAY, T.D. Bone cutting, placement, and cannibalism? Middle preceramic mortuary patterns of Nanchoc, Northern Peru. Revista Chungará (Arica) 33:63-72, 2001.

SANTORO, C.M.; STANDEN, V.G.; ARRIAZA, B.T.; DILLEHAY, T.D. Archaic funerary pattern or postdepositional alteration? The Patapatane burial in the higlands of South Central Andes. Latin American Antiquity 16:329-346, 2005.

SOLARI, A.; SILVA, S.F.S.M. Sepultamentos secundários com manipulações intencionais no Brasil: um estudo de caso no sítio arqueológico Pedra do Cachorro, Buíque, Pernambuco, Brasil. Bol. Mus. Para. Emílio Goeldi. Cienc. Hum. 12:135-155, 2017. 
STECKEL, R.H.; LARSEN, C.S.; SCIULLI, P.W.; WALKER, P.L. Data collection codebook. http://global.sbs.ohio-state.edu.2006.

STRAUSS, A. As práticas mortuárias dos caçadores-coletores pré-históricos da região de Lagoa Santa (MG): um estudo de caso do sítio arqueológico "Lapa do Santo". Dissertação de mestrado. Universidade de São Paulo, São Paulo.2010.

STRAUSS, A. As práticas mortuárias dos caçadores-coletores pré-históricos da região de Lagoa Santa (MG): um estudo de caso do sítio arqueológico "Lapa do Santo". Revista Brasileira de Arqueologia 24:136-139, 2011.

STRAUSS, A. Possibilidades e limitações interpretativas da Hipótese Saxe/Goldstein. Bol. Mus. Para. Emílio Goeldi. Cienc. Hum. 7:525:546, 2012.

TALAMO, S.; RICHARDS, M. A comparison of bone pretreatment methods for AMS dating of samples $>30,000$ BP. Radiocarbon 53, 443-449 (2011).

TEN KATE, H. Sur les Crânes de Lagoa Santa. Bull Soc Anthropol. Paris 8:240-244, 1885.

VAN KLINKEN, G. J. Bone Collagen Quality Indicators for Palaeodietary and Radiocarbon Measurements. J. Archaeol. Sci. 26, 687-695 (1999).

WALTER, H.V.; CATHOUD, A.; MATTOS, A. The Confins Man. A contribution to the study of Early Man in South America. In: MACCURDY, G.G. (ed.). Early Man - As depicted by leading authorities at the international symposium the Academy of Natural Sciences Phyladelphia. J.B. Lippincott Company, London. 1937.

WALTER, H.V. Arqueologia da região de Lagoa Santa. Rio de Janeiro: SEDEGRA. 1958.

WOODBURN, J. Social dimensions of death in four African hunting and gathering societies. In: Bloch M, Perry M. (Eds.) Death and regeneration of life. Cambridge: Cambridge University Press, 1982. 